\title{
The Fruitless Branch and the Eternal Security of the Believer
}

\author{
Anthony Yaw Badu1 (iD Jonathan E.T. Kuwornu-Adjaottor ${ }^{1}$ \\ 1 Department of Religious Studies, Kwame Nkrumah University of Science and Technology (KNUST), Kumasi, Ghana.
}

\begin{abstract}
The quest for the identification of the fruitless branch has been an enduring theological battleground between the Calvinists and the Arminians who argue as to whether or not the removal of the fruitless branch indicates the loss of eternal salvation. Using a qualitative approach, this study sought to examine the various interpretations on the eternal security of the believer with a focus on three phrases in the passage namely; $\dot{\varepsilon} v \dot{\varepsilon} \mu o \grave{l}$, (in me) and airō (cut off) and $\mu \varepsilon \dot{i} v \alpha \tau \varepsilon \dot{\varepsilon} v \dot{\varepsilon} \mu o{ }^{\prime}$ (abide in me). Findings show that the analogy of the vine is a critique to the belief of once saved, forever saved because of the use of "in me" and the "cutting off" of the fruitless branch which cannot happen without a prior linkage to the stem of the vine. Since the fruitless branch can only represent one of the various views, it is recommended that fruitfulness should be the key to one's walk with the Lord to avoid eternal separation.
\end{abstract}

Correspondence Anthony Yaw Badu Email: tonbadu@yahoo.com Publication History Received 28th October, 2021 Accepted 21st January, 2022 Published online 2nd February, 2022

Keywords: Eternal, Salvation, Fruitless, Vine

(C) 2022 The Author(s). Published and Maintained by Noyam Publishers.

This is an open access article under the CCBY license (http://creativecommons.org/licenses/by/4.0/).

\section{INTRODUCTION}

The analogy of the vine in John 15:1-6 has aroused exegetical problems which have resulted in divergent views in the interpretation of the text in regards to the eternal security of the believer. ${ }^{1}$ Jesus in his discourse of the vine did not identify the branches with a particular group of his followers but two kinds of branches; the fruitful and the fruitless branches. Calvinists contend that the soul of true believers is eternally secure in Christ whereas the Arminians postulate that there is a possibility for true believers to forfeit their salvation. ${ }^{2}$

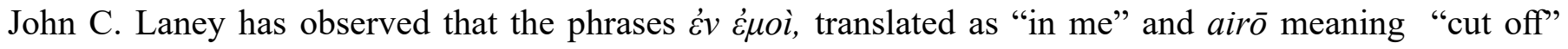
appear to be a problem for this interpretation. ${ }^{3}$ Questions raised in this paper are; is the New Testament vine a total or partial replacement of the Old Testament vine which has become corrupted? ${ }^{4}$ What does Jesus mean by the phrase "in me," ('ُv É $\mu o i)$ and again does the "cut off" (airō) refer to a believer or unbeliever in Christ? If the fruitless branch represents unbelievers, how can they be in the vine who is the Christ?

Charles R. Smith, "The Unfruitful Branches in John 15," Grace Journal, 9, no. 2 (1968): 3; Gary W. Derickson, "Viticulture and John 15:1-6," Journal of the Grace Evangelical Society, (2005): 24. Historically, Calvinists and Arminians have argued about the eternal security of the believer.

2 Smith, "The Unfruitful Branches in John 15," 3.

3 John C. Laney, Lexham Geographic Commentary on the Gospels, (Bellingham, WA: Lexham Press, 2016$), 435$.

4 Robert Dean Jr. “Abiding in Christ: A Dispensational Theology of the Spiritual Life,” CTS Journal 7, (2001): 25. 
On the other hand, what will be the spiritual condition and the destiny of the fruitless branch if it represents believers in Christ and lastly, is there a possibility for apostasy? ${ }^{5}$

After considering several commentaries, articles, journals and some selected eminent theologians, this study seeks to state that the fruitless branch mentioned in Jesus' discourse cannot represent both a believer and an unbeliever. Therefore, the study argues in line with Adam Clarke's submission as the most consistent and logical view with a literal interpretation of the passage, a distinction between those who abide in Christ and those who make a superficial commitment to the lordship of Christ and the consequent effects of not abiding in Christ who is the true vine. The focus will be on three key phrases; $\dot{\varepsilon} v$ É $\mu o i$ (in me), airō (cut off) and $\mu \varepsilon i v \alpha \tau \varepsilon \dot{\varepsilon} v \dot{\varepsilon} \mu o i$ (abide in me) in the analogy of the vine to examine the various interpretations in regards to the identification of the fruitless branch and the consequent result that follows its failure to abide in the vine in relation to the eternal security of the believer.

\section{METHODOLOGY}

The study employs the qualitative approach and gathered data through semi-structured interviews. Due to the nature of the study, heads of Orthodox and Charismatic and Pentecostal churches in Ghana were chosen. Seasoned ministers of the Gospel such as the Most Rev. Peter Kwasi Sarpong, the Roman Catholic Archbishop Emeritus, Rev. Dr. Kojo Osei-Wusu, the former president of the Ghana Baptist Convention, Pastor Ransford Obeng, the founder and head pastor of Central Charismatic Church, were interviewed to share their views on the identity of the fruitless branch and the eternal security of the believer. Also, works of scholars on the subject such as Adam Clarke, Charles R. Smith, John C. Laney, Joseph C. Dillow, John MacArthur Jr. and others were discussed.

\section{The Replacement View}

The Old Testament vine was an imagery and a symbol of the Jewish nation. During the intertestamental period, it was an emblem on the coins of the Maccabees and a golden vine which was one of the glories of the temple. ${ }^{6}$ However, the nation Israel which was God's choice vine; an esteemed symbol became demeaned, strange and empty vine. ${ }^{7}$ A careful investigation of the Old Testament shows a debased and corrupted vine which the prophets Isaiah, ${ }^{8}$ Jeremiah, ${ }^{9}$ Ezekiel ${ }^{10}$ and Hosea ${ }^{11}$ all kept lamenting about its degeneration state. ${ }^{12}$ According to Warren W. Wiersbe, the nation Israel represents the past vine which God "transplanted" into Canaan but did not flourish after all the profound care given to it. ${ }^{13}$ Therefore, the vine in this passage is a new and productive vine which stands in contrast to the prominent biblical symbol that portrays the nation Israel as unproductive. ${ }^{14}$ The unproductiveness of the past vine was evident to Jesus' audience so when Jesus chose the vine in making his final claim of the IAM predictions, he had in mind the goal of juxtaposing the two vines (the past and the present vines) and to distinguish the present vine from all the other vines

\footnotetext{
Laney, Lexham Geographic Commentary on the Gospels, 435.

William Barclay, The Gospel of John, 2, rev, ed., (Philadelphia, Pennsylvania: Westminster Press, 1975), 173.

Barclay, The Gospel of John, 213.

8 Raymond E. Brown, An Introduction to the New Testament, (New York: Doubleday, 1997), 354. With all the consummate care God provided, Israel had not been the vine it was meant to be, it had become debased. It shall be trampled down and lay waste.

9 Barclay, The Gospel of John, 213. God's message to Israel through the prophet Jeremiah was that he had planted Israel as a noble vine, a seed of highest quality but been degenerated and become alien vine. Also, see Bruce B. Barton, Gen. ed., The Life Application Study Bible: New King James Version, (Carol Stream: Illinois, Tyndale House, 2016), 1296.

10 Barton, The Life Application Study Bible: New King James Version, 1437. Ezekiel describes Israel as a fruitful vine with strong branches but dried up, consumed and planted in the wilderness and her fruit devoured.

11 Barton, The Life Application Study Bible, 1536. For Hosea, Israel has become empty and selfish vine bring forth fruit for herself.

12 Smith, "The Unfruitful Branches in John 15," 6.

13 Warren W. Wiersbe, The Wiersbe Bible Commentary: New Testament, $2^{\text {nd }}$ ed., (Italy, David Cook, 2007$), 283$.

14 Smith, "The Unfruitful Branches in John 15," 6.
} 
mentioned in the Old Testament hence the claim, 'I am the true vine.' ${ }^{15}$ Thus, the new vine mentioned in Jesus' discourse is different from the old vine mentioned in the Old Testament. ${ }^{16}$ The Old Testament vine which was a symbol of the Jewish nation composed of both believers and unbelievers and serves as the antecedent in the interpretation of the New Testament vine because Jesus came to fulfil the Scriptures. ${ }^{17}$ For Dean, the vine in the Old Testament includes both believers and unbelievers and therefore, the cut-off branches were only 'professing' believers and not genuine ones. ${ }^{18}$ The Old Testament vine is a shadow of the New Testament vine embodied in Christ, therefore since it was a shadow of what is to come, it could not perform the functions assigned to it but Christ fulfills all the functions expected of the vine hence the adjective the 'true' vine.

\section{An Exegetical Problem}

\section{The Fruitless Branches Are Believers}

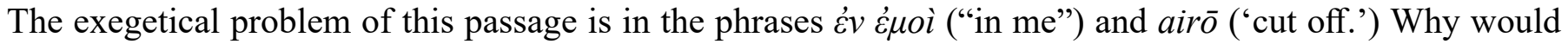
Jesus choose to use these phrases and who is he referring to? Those who hold the view that the fruitless branch represents a believer in Christ strongly emphasize the phrase "in me." Inasmuch as the true vine does not fail to provide the needs of the branches, the branches as well have the responsibility of abiding in the vine for continuous feeding and fruit-bearing. ${ }^{19}$ Therefore, as branches are united with the stem of a tree just as Christ's followers shall abide in him and have the privilege of sharing in his life. ${ }^{20}$ Jesus used the branch both in a general sense referring to his followers as "you" are the branches and also to individual followers as "every" branch. ${ }^{21}$

Does the fruitless branch represent believers in Christ or unbelievers? In outlining various views to this interpretation, Gary Derickson construes that the Arminian view traditionally postulates that the fruitless branches represent those who were once genuine believers but could not persevere in their faith in Christ and became fruitless and thereby forfeited their salvation. ${ }^{22}$ The Arminian according to Lewis S. Chafer fortifies the claim of insecurity in John 15:6 of the viticulture analogy in which fruitless branches are cut off and burned. ${ }^{23}$

Clarke submits that a person may truly be united to Jesus who is the true vine and be cut off into the fire. ${ }^{24} \mathrm{He}$ explains that it will be illogical to cut off a branch from a tree that was never united to the tree, this will be absurd and inconsistent with the spirit of the metaphor. ${ }^{25} \mathrm{He}$ then elucidates that a superficial union requires only a superficial removal. ${ }^{26}$ Clarke's submission according to Charles Smith is the most explicit interpretation given by those who hold the Arminian view. ${ }^{27}$

Interpreting the Arminian view, Joseph C. Dillow draws from the viticulture practice where fallen vines are lifted up with consummate care to be fruitful during growing seasons after they were made to lie down for a period during the winter. ${ }^{28}$ Dillow argues that fruitless branches receive some form of nurturing but are cast off when they are unable to bear fruit. ${ }^{29} \mathrm{He}$ further asserts that fruitless branches are disobedient

15 Barclay, The Gospel of John, 213.

16 Dean, Jr., "Abiding in Christ," 28

17 An Interview with Kojo Osei-Wusu, the former President of the Ghana Baptist Convention and the Ghana Baptist University College, Kumasi, Ghana on the $3^{\text {rd }}$ September, 2021.

18 Dean, Jr., "Abiding in Christ," 28.

19 Laney, Lexham Geographic Commentary on the Gospels, 438.

20 Wiersbe, The Wiersbe Commentary, 283.

21 Laney, Lexham Geographic Commentary on the Gospels, 438.

22 Derickson, "Viticulture and John 15:1-6," 24.

23 Lewis Sperry Chafer, “The Eternal Security of the Believer," Bibliotheca Sacra, 106, (1949): 402.

24 Adam Clarke, The New Testament with Commentary and Critical Notes, I, (New York: Lane \& Scott., 1850), 626/7.

25 Clarke, The New Testament with Commentary and Critical Notes, 626/7.

26 Clarke, The New Testament with Commentary and Critical Notes, 627.

27 Smith, "The Unfruitful Branches in John 15," 7.

28 Laney, Lexham Geographic Commentary on the Gospels, 436.

29 Joseph C. Dillow, “Abiding is Remaining in Fellowship: Another Look at John 15:1-6,” Biblotheca Sacra 147, (1990): 44. 
believers and not those who falsely profess the faith. ${ }^{30}$ Dillow's interpretation has been refuted as contrary to Jesus' teaching in John 10:28-29 that those who come to him shall never perish. ${ }^{31}$ According to this view, the Bible does not suggest that believers will undergo a judgment by fire where they themselves are burned. ${ }^{32}$ John F. MacArthur Jr. contends that the imagery of burning implies that the fruitless branches are domed to hell, they are like Judas and are hopeless apostates. ${ }^{33}$ Peter Kwasi Sarpong succinctly explains that the fruitless branch represents a believer and that salvation in Christ is conditioned upon the perseverance of the believer hence Jesus emphasized the 'abide in me' as a caveat to the believer. ${ }^{34}$ This view is shared by both Kojo Osei-Wusu and Ransford Obeng that Jesus' emphasis on 'abide in me' presupposes that the believer in Christ has the responsibility of abiding in his walk with the Lord. It calls for a personal commitment to obey the Lord which is a mark of a true believer. Osei-Wusu added that one cannot live like the devil and go to heaven. ${ }^{35}$ Obeng strongly argues in line with the Lordship of Christ. He explains that belief goes beyond mental faith, when a person accepts Christ as Lord and Savior and begins to practice the faith, then Christ embodies the person and faith becomes real. ${ }^{36}$

\section{Fruitless Branches Are Nonbelievers}

This view postulates that the fruitless branches are nonbelievers within the visible church and that they are "unsaved professors." ${ }^{37}$ The $\dot{\varepsilon} v \dot{\varepsilon} \mu o i$ ("in me") according to Calvin, awakes an "anxious inquiry" ${ }^{38}$ that those who follow Christ should be fruitful else they will be severed from him. It will be a contradiction for someone grafted into Christ to be without fruit. ${ }^{39}$ Robert Coleman explains that the vine has a life sustaining power and the purpose for those grafted into the vine is to bear fruit. ${ }^{40}$ Coleman used the parable of the Sower to explain the fruitless branches as those who allow the cares of the world, the deceitfulness of riches, and the lusts of other things to choke out the Word of God planted in their hearts. When such happens, according to Coleman, the Christian life becomes fruitless. ${ }^{41}$

Calvin uses the word "Vital Sap" to describe what Coleman refers to as life sustaining power that gives human beings who are naturally incapable of accomplishing anything fruitful to be fruitful. In examining this assertion, there are those who are supposedly considered to be in the vine, who actually are not because they only make a superficial commitment with no inner conviction or have no root in the vine, because, it is required of a fruit-bearing plant to have a living root in the vine. This view is explicit that the fruitless branch represents those who made only an outward professing of faith with no inner conviction. ${ }^{42}$ On the excision of the fruitless branch, this view holds that those who are cut off are just followers who have no conviction. Laney contends that there are two kinds of disciples; believing and unbelieving disciples.

30 Dillow, "Abiding is Remaining in Fellowship," 44.

31 Laney, Lexham Geographic Commentary on the Gospels,

32 Laney, Lexham Geographic Commentary on the Gospels, 439.

33 John F. MacArthur Jr., The Gospel According to Jesus, rev. ed. (Grand Rapids: Zondervan, 1994), 173. MacArthur explains that these fruitless branches may be eminent church members, those who have acquired spiritual knowledge, teachers and even scholars however, if they do not have genuine faith, God will remove them.

34 An interview with the Most Rev. Peter Kwasi Sarpong, the Roman Catholic Archbishop Emeritus of Kumasi on the $15^{\text {th }}$ of September 2021.

35 An Interview with Kojo Osei-Wusu, $3^{\text {rd }}$ September, 2021.

36 An Interview with Ransford Obeng, the Head Pastor of Calvary Charismatic Church, Ayigya Kumasi on the $13^{\text {th }}$ September, 2021.

37 Smith, "The Unfruitful Branches in John 15," 10.

38 Calvin John, Commentary on the Gospel According to John, Vol.2, trans. William Pringle, (Grand Rapids, MI: Christian Classics Ethereal Library), 62. http://www.ccel.org/ccel/calvin/calcom35.html

39 Robert E. Coleman, The Master Plan of Evangelism with study guide by Roy. Fish, (Tarrytown, New York: Fleming H. Revell Company, 1991), 107.

40 Coleman, The Master Plan of Evangelism, 107.

41 Coleman, The Master Plan of Evangelism, 107.

42 Calvin, Commentary on the Gospel According to John, 63. 
Unbelieving disciples are those who could not accept Jesus' teachings and turned away from following him at Capernaum. ${ }^{43}$ Such disciples will have their superficial union with Christ severed because they were not connected to him from the beginning. Cory Mash argues that the fruitless branch refers to Judas Iscariot, who seemed to be "in" the Vine; but actually, he never dwelt in Him and was fruitless. ${ }^{44}$ False professors are spiritually fruitless because even though salvation is not by works, however, works are the only proof of one's genuine faith in Christ which is vibrant and alive. ${ }^{45}$ According to Harry A. Ironside, the soul of the believer is eternally secure and will not have their names blotted out from the book of life. ${ }^{46}$ Ironside explains that Jesus' words “I never knew you," in Matthew 7:23 does not mean those rejected were once believers and have forfeited their salvation. Rather, such people had never been partakers of the divine grace even though they were actively involved in Christian work and have accomplished many great works. ${ }^{47}$

However, notwithstanding the Calvinist's claim that fruitless branches are nonbelievers, a second view within the Calvinists asserts that fruitless branches represent believers who are temporarily disciplined by means of death but do not forfeit their salvation. ${ }^{48}$ They are of the view that the fruitless branch represents true believers in Christ but due to their fruitlessness, and in order not to lose their salvation, they undergo temporal discipline hence the phrase, "cut off" which is interpreted as temporal death and that they will be saved as though through fire. ${ }^{49}$ On the contrary, Laney argues that the removal of the fruitless branches is an indication of an impending judgment and not a blessed fellowship with Christ in heaven. ${ }^{50}$ The burning fire in verse six is in relation to the fruitless branches, not their works as described in 1Corinthians 3:15.

Marsh has observed that Jesus appears to describe the branch superficially "in" the vine and suggests that he might probably be referring to one of his disciples, the traitor, and all those who will be pretenders like him hence the phrase "in me." 51 He however, concludes by admitting that there is an ambiguity due

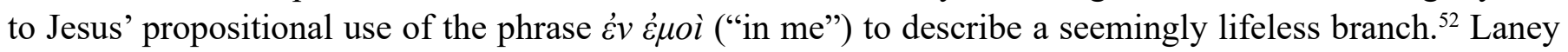
explains that the phrase $\dot{\varepsilon} v \dot{\varepsilon} \mu o \grave{~(" i n ~ m e "), ~ s h o u l d ~ b e ~ t a k e n ~ a s ~ a n ~ a d j e c t i v e ~-o r ~ a n ~ a d v e r b ~ a n d ~ s h o u l d ~ b e ~ r e a d ~}$ as "Every branch that does not bear fruit in me, he takes away." (ESV) ${ }^{53} \mathrm{He}$ further explains that fruit-bearing is a process and it happens only when one is connected to Christ, the life-giver. ${ }^{54}$ The true vine that gives life will not fail to supply the needs of the branches but the branch that fails to bear fruit will fall and be burned. Having considered carefully the interpretations offered by scholars and theologians on the subject, it is the author's view that the fruitless branch refers to a believer in Christ. The branch has both a privilege to be in the vine as well as a responsibility of bearing fruit. Privileges do not require good works but responsibility requires. Therefore, if the Old Testament vine failed to be productive and became debased, then a believer in Christ who consistently becomes fruitless after all the privileges given by the Lord may be severed from the vine who is the Christ because one cannot live anyhow and please the LORD.

\section{The Abiding Model}

The phrase, $\mu \varepsilon i v \alpha \tau \varepsilon \dot{\varepsilon} v \dot{\varepsilon} \mu o$ i translated as "abide or remain in me" indicates that there is a divine providence as well as human responsibility. Branches have privileges of sharing in the life of the vine and are also obliged to continuously abide in the vine for fruit-bearing. ${ }^{55}$ The abiding model seeks to explain some concepts in

43 Laney, Lexham Geographic Commentary on the Gospels, 435.

44 Cory Marsh, “Jesus, The True Vine: An Exegesis of John 15:1-5,” (M.A. Diss., Southern California Seminary, 2017$), 27$.

45 MacArthur Jr., The Gospel According to Jesus, 170.

46 Harry A. Ironside, The Eternal Life of the Believer, (Chicago, Illinois: 1934), 31.

47 Ironside, The Eternal Life of the Believer, 3.

48 Derickson, "Viticulture and John 15:1-6," 24.

49 Dillow, "Abiding is Remaining in Fellowship," 44.

50 Laney, Lexham Geographic Commentary on the Gospels, 439.

51 Marsh, "Jesus, The True Vine," 24.

52 Marsh, "Jesus, The True Vine," 24.

53 Laney, Lexham Geographic Commentary on the Gospels, 438.

54 Laney, Lexham Geographic Commentary on the Gospels, 438.

55 Wiersbe, The Wiersbe Bible Commentary, 283. 
the believer's relationship with Christ, the true vine who provides the vital sap for believers in their walk with him.

The abiding is a union with Christ. ${ }^{56}$ This union is a mixture of human and divine natures in which the believer is hidden in the unseen root of the vine who is Christ. ${ }^{57}$ By this union, Christ is formed in the believer and shares Christ's divinity which makes fruit-bearing something natural in the life of the believer. ${ }^{58}$ A union with Christ leads to the deification of the believer. ${ }^{59}$ Simeon in his submission argues that uniting with someone means sharing the person's nature and essence. ${ }^{60}$ This deification view, according to Alister E. McGrath, represents the Eastern Orthodox Christian view of salvation. ${ }^{61}$ This abiding model is both a mutual union and also on an individual basis. It is a union with Christ which is a living, loving and lasting union. As a living union, it leads to fruit-bearing, in a loving union, one enjoys a relationship with Christ and the lasting union secures one's relationship with Christ. ${ }^{62}$

Abiding is a communion. Chafer argues contrary to the union concept. For Chafer, "abiding" does not refer to a union but communion because the focus of the passage is on the believer's walk, therefore, the believer's failure to abide leads to discipline from the Lord. ${ }^{63}$ Chafer explains communion as a walk with God and not a union which makes the believer share in the essence of Christ. His emphasis on communion rather than union stems from the fact that a believer can fail to abide in Christ and therefore, a union with Christ makes the severing of the believer somehow impossible. ${ }^{64}$

The abiding is an unreserved commitment to Christ. ${ }^{65}$ Helmut Haubeil defines abiding as a constant receiving of His Spirit, a life of unreserved commitment to His service. ${ }^{66}$ Those who have received cleansing must abide in him in order to bear fruit because fruit is the only possible validation that a branch is abiding in the true vine, thus the absence of fruit demonstrates the absence of life. ${ }^{67}$ As vine produces grapes, so do people look for Christian temper, disposition and life in the believer who abides in Christ. ${ }^{68}$

Abiding is believing in Christ. ${ }^{69}$ According to Laney, the Greek word, $\mu \varepsilon ́ v \omega$, "menō" means to remain or to stay. It is a continuous, lasting relationship. ${ }^{70} \mathrm{He}$ further explains that the gospel of John consistently used the verb 'believe' as parallel to 'abiding' because everyone who believes also abides in him. Therefore, to confess Jesus as Lord leads to abiding in him, anyone who does not abide does not have a relationship with the life-giver. ${ }^{71}$

Abiding is fellowship. Laney then posits that 'to abide' is to have a reciprocal relationship with Jesus. If genuine believers remain in him, then he promises to remain in them also. ${ }^{72}$ Therefore, fruitfulness is a result of a living union with Christ the True Vine. Dillow agrees with Laney on the interpretation of abiding as a means of fellowship with Christ but differs on the issue of the "non-abiding" disciples. According to

\footnotetext{
56 Matthew Henry, Matthew Henry's Concise Commentary on the Bible, (Grand Rapids, MI: Christian Ethereal Library, 969. http://www.ccel.org/ccel/henry/mhcc.html

57 Henry, Matthew Henry's Concise Commentary on the Bible, 969.

58 Henry, Matthew Henry's Concise Commentary on the Bible, 969.

59 Simon the New Theologian, "Salvation as Deification," The Christian Theology Reader, $3^{\text {rd }}$ ed. Alister E. McGrath, ed., (USA: Blackwell Publishing, 2007), 355. Simeon is one of the Greek patristic writers regarded with special favor by modern Orthodox theologians.

60 Simon, "Salvation as Deification," 355.

61 Alister E. McGrath, ed., The Christian Theology Reader, $3^{\text {rd }}$ ed., (USA: Blackwell Publishing, 2007), 355.

62 Wiersbe, The Wiersbe Bible Commentary, 283.

63 Chafer, "The Eternal Security of the Believer," 402.

64 Derickson, "Viticulture and John 15:1-6," 25.

65 Helmut Haubeil, Abiding in Me, $3^{\text {rd }}$ ed. (Wien, Austrian: Top Life Wegweiser-Verlag, 2019), 4.

66 Haubeil, Abiding in Me, 4.

67 Michael D. Coogan, ed. The New Oxford Annotated Bible: Augmented Third Edition with the Apocryphal/Deuterocanonical Books, (New York: Oxford University Press, 2007), 173.

68 Henry, Matthew Henry's Concise Commentary on the Bible, 969.

69 Laney, Lexham Geographic Commentary on the Gospels, 437.

70 Laney, Lexham Geographic Commentary on the Gospels, 438.

71 Laney, Lexham Geographic Commentary on the Gospels, 438.

72 John C. Laney, “Abiding is Believing: The Analogy of the Vine in John 15:1-6,” Bibliotheca Sacra, 146, (1989): 55.
} 
Dillow, "abiding" means remaining in fellowship with Christ in keeping his commandments. However, those who do not abide should not be considered as 'false professors' but rather, disobedient believers. Such people according to Dillow will not lose their salvation but their fellowship with the Lord. ${ }^{73}$ Robertson explains the phrase, 'to abide' in Christ to mean to 'continue believing' which also implies that to discontinue abiding presupposes a prior union with Christ. ${ }^{74}$

Abiding is a continuing dependence on Christ. ${ }^{75}$ Jesus gave this analogy in view of his departure asserting that branches are worthless if they do not have a connection with the vine and therefore, believers are nothing apart from Christ who is the giver of life. ${ }^{76}$ Jesus calls for a total commitment from his disciples as the only way to succeed in life. According to Robertson, Jesus' words, "abide in me" carries an implicit aspect of human agency therefore, the "continuous abiding" depends on the believer, not on Jesus. ${ }^{77}$ The abiding model assumes that the Christian life is not a static and an unalterable union but rather a mutual union in which the believer and Christ dwell in each other through the Holy Spirit. Robertson describes the union between Christ and the believer as "perichoresis," a term used to describe the relationship that exists between the Godhead. ${ }^{78}$ Any time fruit-bearing is mentioned, the word is in the present tense implying that the Greek text is a continuous reproduction of fruit and not a one-time event. ${ }^{79}$ Abiding is fellowship and viewed as the most consistent with a literal interpretation of the passage, a distinction between Israel and the Church.

\section{The Apostasy}

What will be the spiritual condition and the destiny of the fruitless branch if it represents believers in Christ? This question leads to the issue of apostasy as to whether or not the cutting off of the fruitless branch has implications on the eternal security of the believer. The essence of this metaphor is seen only when the cutoff branch has previously been linked to the vine. ${ }^{80}$

To persevere in the Christian life according to Henry is to do good despite difficulties, it is a kind of blessing which is evidence of God's grace upon the believer. ${ }^{81}$

Robertson describes the eternal security of believers as "the assurance that one may have as a believer in Jesus Christ that one's union with Christ through faith will come to fruition in eternal salvation." 82 Robertson explains that there are two schools of thought emerging from the same root of Calvinism, namely; the classical and the moderate Calvinism. The classical Calvinistic view emphasizes election as a key to salvation. It holds that eternal security is a divine decision for only those God has ordained and that those whom God elects, he also produces in them the faith which can make them persevere to the end. ${ }^{83}$ The moderate Calvinist rejects one of the key tenants of the classical Calvinism which is election but holds the view that those who have responded to Christ in faith will be preserved, for, God has imputed to them the redemptive work of Christ and they have God's promise of salvation for all those who believe. ${ }^{84}$

Ian Howard Marshall has observed that those who uphold the possibility of apostasy are fully aware that those who continue to abide have the promise of perseverance. However, from the Calvinist perspective, the promise of perseverance is an inadequate form of assurance and argues that the ability to persevere

73 Dillow, "Abiding is Remaining in Fellowship," 53.

74 Gregory Robertson, "Eternal Security: A Biblical and Theological Appraisal," (A Paper prepared for the Doctrinal Dialogue for the $119^{\text {th }}$ North American Convention of the Church of God, Anderson, Indiana, 2005$), 7$.

75 Derickson, "Viticulture and John 15:1-6," 38.

76 Derickson, "Viticulture and John 15:1-6," 38.

77 Robertson, "Eternal Security," 7.

78 Robertson, "Eternal Security," 7.

79 Coleman, The Master Plan of Evangelism, 107.

80 Clarke, The New Testament with Commentary and Critical Notes, 627.

81 Henry, Matthew Henry's Concise Commentary on the Bible, 1007.

82 Robertson, "Eternal Security," 2.

83 Robertson, "Eternal Security," 2.

84 Robertson, "Eternal Security," 2. 
comes from the Lord which also rules out the believer's freedom. ${ }^{85}$ Marshall then explains that it comforts the believer in Christ to know that God is always ready to forgive the backslider whenever the person turns to him for forgiveness. However, knowing how fallible human beings are, those who hold the impossibility view want the assurance that they can never turn away from the Lord to such an extent that they cannot come back to him. ${ }^{86}$ This view according to Marshall, postulates that even though believers in Christ may fall into sin, the Lord will guard those believers that they may not sin to such an extent that they can never hear the voice of the Lord. ${ }^{87}$

Moses C. Onwubiko argues that since salvation is not based on works but on grace it is therefore difficult for legalistic believers to get over the doctrine of eternal security. Onwubiko strongly affirms that regardless of the lifestyle of the believer, he will be saved. According to him, the only major concern a carnal believer should have is this "fire," as the apostle Paul said in 1Cor. 15:15.88

What kind of faith does one need to persevere to the end? Martin Luther defines faith in two ways; faith as a noun and faith as a verb. Faith as a noun is a belief in historical facts and faith as a verb is living in relation to God. ${ }^{89}$ Faith that relates to historical facts is concerned with the works of Christ which are found in creeds. The other meaning of faith helps believers to see the practical meaning of the historical Christ and enables them to have a personal relationship with God. To Luther, this personal faith is the key to one's justification in Christ which he calls the saving faith. ${ }^{90}$ Emphasizing the importance of justification, Luther said:

"When the article of justification has fallen, everything has fallen. This is the chief article from which all other doctrines have flowed. It alone begets, nourishes, builds, preserves, and defends the Church of God. Without it, the Church of God cannot exist for one hour. It is the master and prince, the lord, the ruler, and the judge over all kinds of doctrines." 91

\section{CONCLUSION}

The exegesis of the text has shown that Jesus chose his words carefully and every word he uttered has its meaning in the analogy he put forth. The word "branch" used in this analogy occurs only once in the New Testament. ${ }^{92}$ It shows the uniqueness of the passage and how it encompasses a lot of issues bringing in major doctrinal issues like the eternal security of the believer and also serving as a critique of the view of once saved forever saved. Many have offered suggestions as to the exact occasion Jesus made the analogy of the vine, however, one that comes close is the view of his departure in which Christ was making his final discourse emphasizing that even though his life here on earth is coming to an end, his disciple will need a continuous relationship with him for a successful life. ${ }^{93}$ The phrase "in me" which has generated debate as to the identification of those Jesus meant in his phrase will continue unabated. Both Calvin and Clarke have made profound statements which will continue to engage the minds of scholars as to the validity of these statements. $^{94}$

\footnotetext{
85 Ian Howard Marshall, "The Problem of Apostasy in the New Testament Theology," Perspectives in Religious Studies (Aberdeen, Scotland: University of Aberdeen, 1987), 68.

86 Marshall, "The Problem of Apostasy in the New Testament Theology," 68.

87 Marshall, "The Problem of Apostasy in the New Testament Theology," 68.

88 Moses C. Onwubiko, Eternal Security of the Believer, (Nashville, U.S.A: Grace Evangelistic Ministries, Inc., 2010$), 11$.

89 Hans. H. Kramm, The Theology of Martin Luther, (London: Clarke \& Co. Ltd., 1946), 51.

90 Kramm, The Theology of Martin Luther, 51.

91 Mark Water, The New Encyclopedia of Christian Quotations, (Grand Rapids, Michigan: Baker Books, 2000$), 552$.

92 Smith, "The Unfruitful Branches in John 15," 20.

93 Brown, An Introduction to the New Testament, 334.; Smith, "The Unfruitful Branches in John 15," 4.

94 Calvin, Commentary on John's Gospel, 63.; Clarke, The New Testament with Commentary, 267.
} 


\section{BIBLIOGRAPHY}

Barclay, William. The Gospel of John, 2, rev, ed., Philadelphia, Pennsylvania: Westminster Press, 1975.

Barton, Bruce B. The Life Application Study Bible: New King James Version, Carol Stream, Illinois: 2016. Brown, Raymond E. An Introduction to the New Testament, New York: Doubleday, 1997.

Calvin, John. Commentary on the Gospel According to John, Vol.2, trans. William Pringle, Grand Rapids,

MI: Christian Classics Ethereal Library. Accessed March 29, 2021.

http://www.ccel.org/ccel/calvin/calcom35.html

Chafer, Sperry Lewis. "The Eternal Security of the Believer," Bibliotheca Sacra, 106, (1949): 402.

Clarke Adam, The New Testament with Commentary and Critical Notes, I, New York: Lane \& Scott., 1850.

Coleman, Robert E. The Master Plan of Evangelism with study guide by Roy. Fish, Tarrytown, New York:

Fleming H. Revell Company, 1991.

Coogan, Michael D. ed. The New Oxford Annotated Bible: Augmented Third Edition with the Apocryphal/

Deuterocanonical Books, New York: Oxford University Press, 2007.

Derickson, Gary W. "Viticulture and John 15:1-6," Journal of the Grace Evangelical Society, (2005): 23-43.

Dillow, Joseph C. “Abiding is Remaining in Fellowship: Another Look at John 15:1-6," Biblotheca Sacra

$147,1990$.

Haubeil, Helmut. Abiding in Me, $3^{\text {rd }}$ ed. Wien, Austrian: Top Life Wegweiser-Verlag, 2019.

Henry, Matthew. Matthew Henry's Concise Commentary on the Bible, Grand Rapids, MI: Christian Ethereal

Library. Accessed May 21, 2019. http://www.ccel.org/ccel/henry/mhcc.html

Ironside, A. Harry. The Eternal Life of the Believer, Chicago, Illinois: 1934.

Kramm, Hans H. The Theology of Martin Luther, London: Clarke \& Co. Ltd., 1946. Journal of Emerging

Trends in Educational Research and Policy Studies, 3 no. 4 (2012): 575-579.

Laney, John C. “Abiding is Believing: The Analogy of the Vine in John 15:1-6," Bibliotheca Sacra, 146, (1989).

. Lexham Geographic Commentary on the Gospels, Bellingham, WA: Lexham Press, 2016.

MacArthur, Jr. John F. The Gospel According to Jesus, rev. ed. Grand Rapids: Zondervan, 1994.

Marsh, Cory. "Jesus, The True Vine: An Exegesis of John 15:1-5." M.A. Diss., Southern California Seminary, 2017.

Marshall, Ian Howard. "The Problem of Apostasy in the New Testament Theology," Perspectives in Religious Studies, Aberdeen, Scotland: University of Aberdeen.

McGrath, Alister E. ed., The Christian Theology Reader, $3^{\text {rd }}$ ed., USA: Blackwell Publishing, 2007.

Robertson, Gregory. "Eternal Security: A Biblical and Theological Appraisal," A Paper prepared for the

Doctrinal Dialogue for the $119^{\text {th }}$ North American Convention of the Church of God, Anderson, Indiana, 2005.

Simon, the New Theologian. "Salvation as Deification," The Christian Theology Reader, $3^{\text {rd }}$ ed. Alister E.

McGrath, editor. USA: Blackwell Publishing, (2007): 355-358.

Smith, Charles R. "The Unfruitful Branches in John 15," Grace Journal, 9, no. 2, (1968): 2-22.

Water, Mark. The New Encyclopedia of Christian Quotations, Grand Rapids, Michigan: Baker Books, 2000. Wiersbe, Warren W. The Wiersbe Bible Commentary: New Testament, $2^{\text {nd }}$ ed., Italy, David Cook, 2007.

\section{ABOUT AUTHORS}

Anthony Yaw Badu is a graduate of Baylor University, Waco, Texas-USA. He is currently the Head Pastor of Ascension Baptist Church, Kumasi - Ghana and pursuing PhD program at the Department of Religious Studies, College of Humanities and Social Sciences, Kwame Nkrumah University of Science and Technology, Ghana.

Jonathan Edward Tetteh Kuwornu-Adjaottor is an Associate Professor in New Testament and Mother Tongue Biblical Hermeneutics in the Department of Religious Studies, Kwame Nkrumah University of Science and Technology - Kumasi Ghana. 